\title{
A Case of Granular Cell Tumor of the
Mediastinum Treated by VATS and A Review of Literature*
}

\author{
VATS ile Tedavi Edilen Mediastinal Granüler Hücreli Tümör Olgusu ve \\ Literatür İncelemesi
}

Şevki Mustafa Demiröz' ${ }^{1}$ Göktürk Fındık' , Gülşen Yılmaz' , Funda Demirağ², Pınar Tarı

\begin{abstract}
Granular cell tumors (GCT) of mediastinal origin are extremely rare. To the best of our knowledge there have been a total of 21 cases reported since the first case was reported by Harrer in 1972. Both benign and malign forms of GCTs have been reported, and some criteria for malign forms have been described. Preoperative diagnoses are challenging due to the rareness of the condition. Histopathological studies should include immunhistochemistry. Given the rareness of such tumors in the mediastinum, the findings and the diagnostic yield of PET-CT are still unclear. Herein we present the case of a 50-year-old woman suffering from back pain whose diagnosis was based on a thorax computed tomography followed by PET$C T$, and who was treated with a video-assisted thoracic surgical excision, with a final pathologic diagnosis of a "granular cell tumor" of the posterior mediastinum.
\end{abstract}

Key words: Granular cell tumor, mediastinal tumor, video-assisted thoracic surgery.

\section{Özet}

Mediastinal Granüler Hücreli Tümör (GHT) oldukça nadirdir. Illk kez 1972 yilında Harrer tarafından bildirildiği tarihten beri literatürdeki toplam olgu sayısı $21^{\prime}$ dir. GHT'nin hem benign hem de malign formları bildirilmiş, malignite kriterleri de tanımlanmışır. Oldukça nadir bir tümör olması nedeniyle ayırııı tanıda düşünülmediğinden preoperatif tanısı zordur. Histopatolojik incelemeler mutlaka immünhistokimyasal çalışmaları da içermelidir. Mediastende nadir görülen bir tümörü olduğundan, tanıda PET/BT'nin etkinliği de henüz belirlenmemiştir. Sunulan olguda, sırt ağrısı ile başvuran 50 yaşında bir kadın hastaya, toraks tomografisi ve takiben PET/BT çekilmiş, posterior mediastinal bölgede saptanan lezyona yönelik VATS ile total eksizyon yapılmışıı. Histopatolojik tanı "granüler hücreli tümör" olarak raporlanmıştır.

Anahtar Sözcükler: Granüler Hücreli Tümör, Mediastinal Tümör, Video-yardımlı Göğüs Cerrahisi.

'Department of Thoracic Surgery, University of Health Sciences, Ankara Atatürk Chest Diseases and Thoracic Surgery Training and Research Hospital, Ankara, Turkey

${ }^{2}$ Department of Pathology, University of Health Sciences, Ankara Atatürk Chest Diseases and Thoracic Surgery Training and Research Hospital, Ankara, Turkey

${ }^{3}$ Department of Nuclear Medicine, University of Health Sciences, Ankara Atatürk Chest Diseases and Thoracic Surgery Training and Research Hospital, Ankara, Turkey

\author{
'Sağlık Bilimleri Üniversitesi, Ankara Atatürk Göğüs Has- \\ talıkları ve Göğüs Cerrahisi SUAM, Göğüs Cerrahisi Kliniği, \\ Ankara \\ ${ }^{2}$ Sağlık Bilimleri Üniversitesi, Ankara Atatürk Göğüs Has- \\ talıkları ve Göğüs Cerrahisi SUAM, Patoloji Kliniği, Ankara \\ ${ }^{3}$ Sağlık Bilimleri Üniversitesi, Ankara Atatürk Göğüs Has- \\ talıkları ve Göğüs Cerrahisi SUAM, Nükleer Tıp Kliniği, Anka- \\ ra
}

*The subject case report was presented as a poster in Turkish Toracic Society 22th Congress, held in Antalya, Turkey

Submitted (Başvuru tarihi): 28.08.2019 Accepted (Kabul tarihi): 25.11.2019

Correspondence (iletişim): Şevki Mustafa Demiröz, Department of Thoracic Surgery, University of Health Sciences, Ankara Atatürk Chest Diseases and Thoracic Surgery Training and Research Hospital, Ankara, Turkey

e-mail: demirozsm@gmail.com 
Granular cell tumors (GCT) were first described by Abrikossoff in 1926 as a benign neoplasm that is usually characterized by the emergence of painless nodules in superficial soft tissues $(1,2)$. The most common site of involvement is the head and neck region, accounting for nearly two-thirds of all cases, although they can occur in almost any anatomical location $(3,4)$. Mediastinal GCT is an exceptional tumor. The patient characteristics of the 21 cases reported in literature, including the present case, are summarized in Tables 1 and 2. The aim in this report is to distinguish the different properties of this extremely rare mediastinal form of GCT from those seen in other parts of the body by summarizing all of the cases reported in literature to date.

\section{CASE}

A 50-year-old woman suffering from back pain for nearly one year was admitted to our clinic, with a medical history of thyroidectomy and cholesistectomy operations in recent years. There were no pathological findings upon physical examination. Her thorax computed tomography revealed a $30 \times 18 \mathrm{~mm}$ mass lesion located at the level of the 6th thoracal spine in the right posterior paravertebral region (Figure 1). This mass lesion had pathologic FDG uptake (SUVmax: 4.11) on PET-CT (Figure 2), and a higher FDG uptake identified in the nasopharyngeal region (SUVmax: 13.19) led to an otolaryngology consultation being made. The biopsy obtained from the nasopharyngeal lesion revealed "reactive follicular hyperplasia". There were no pathological findings from a fiberoptic bronchoscopic examination. A video-assisted thoracic surgical excision was planned. A VATS exploration revealed a mass lesion with a smooth and regular surface in the posterior mediastinal region associated with the adjacent sympathetic nerve chain. A total excision was performed.

Upon histopathological examination a $3 \times 2,5 \times 2 \mathrm{~cm}$ sized, solid, yellowish-white mass with a smooth surface with focal areas of bleeding was identified. A microscopic examination revealed a benign lesion with no mitosis, necrosis or nuclear polymorphism, but with an invasion of the fibrous capsule at one point. The tumor was positive for S100 protein, CD68, TFE-3, CD56 and synaptophysin, and negative for EMA and chromogranin in immunohistochemistry. The tumor was also focally positive with PAS staining, and the collagen rich capsula was stained significantly with trichrome. The focal Schwannian differentiation present led a diagnosis of GCT (Figure 3).

\section{DISCUSSION}

Granular cell tumor (GCT) is an uncommon neoplasm of Schwann-cell origin that tends to be mostly benign and asymptomatic $(1,5)$. It was first considered to be a type of myoblastoma, however immunhistochemistrical and electron microscopy studies revealed ultrastructural differences from Schwannian cells (6). It has been reported to occur between the fourth and sixth decades of life, and is more common in women (5). Mediastinal GCT is extremely rare. In this report summarizing all 22 cases of mediastinal GCT reported on to date, we found that patients were between 11 and 66 years of age (median age 34.7), with 11 (50\%) younger than 30 years of age. Although some reports suggest that mediastinal GCT is twice as common in women, we identified only a slight female dominance ( 12 females and 9 males, and one case with unreported gender) (Table 1).

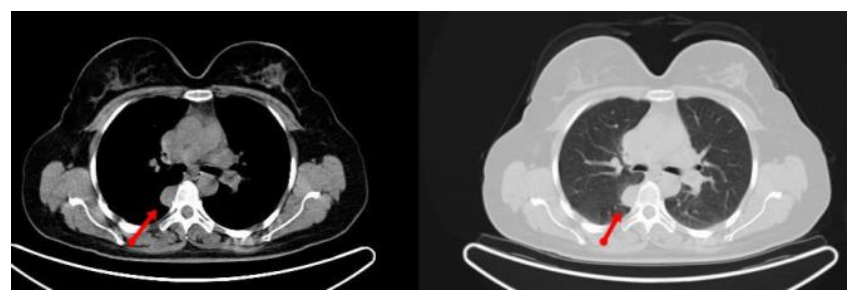

Figure 1: The smooth bounds of the tissue lesion in the right paravertebral area at the T6 vertebra level in PET-CT measured approximately $26 \times 16 \times 31 \mathrm{~mm}$

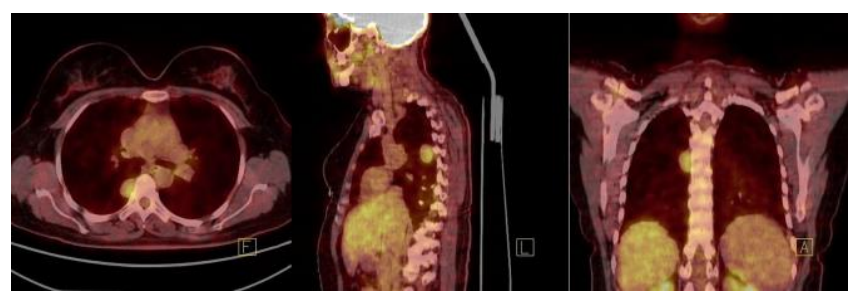

Figure 2: The subject mass lesion on PET-CT (SUVmax: 4.11)

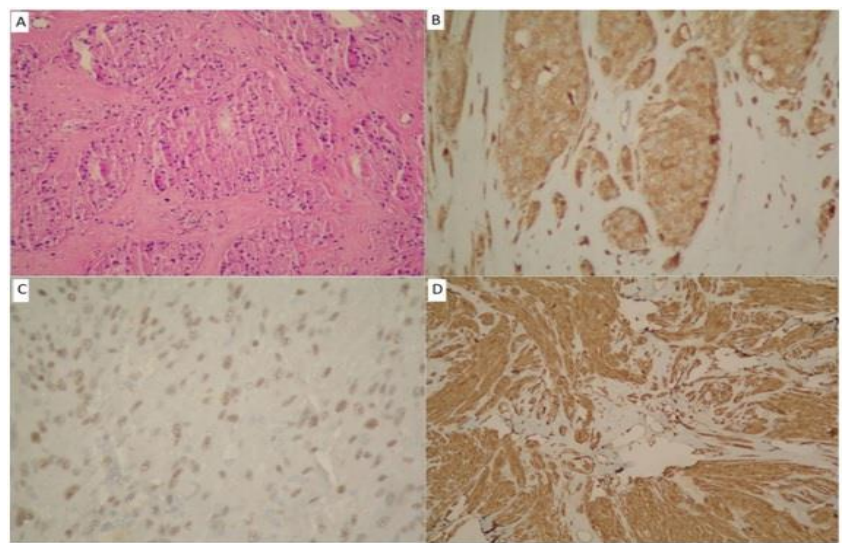

Figure 3: In the Immunohistochemical study, the tumor consisted of oval cells with a hyperchromatic nucleus and granular cytoplasmic cells (HEX200) (A), CD68 positivity in tumor cells (CD68X400) (B), Intranuclear TFE3 positivity in tumor cells (TFE3X400) (C), S100 protein positivity in tumor cells (s100 proteinX40) (D) 
Table 1: Mediastinal GCTs, summary of the literature

\begin{tabular}{|c|c|c|c|c|c|c|}
\hline Case No & Author & Age & Gender & Symptom & Pathology & $\begin{array}{l}\text { Relationship with sym- } \\
\text { pathetic chain }\end{array}$ \\
\hline 1 & 1972_Harrer & 59 & $\mathrm{~F}$ & dyspnea, wheezing & malign & Unknown \\
\hline 2 & 1975_Rosenbloom & 11 & M & asymptomatic & benign & + \\
\hline 3 & 1987_Abenoza & 18 & $\mathrm{~F}$ & asymptomatic & benign & Unknown \\
\hline 4 & 1988_Aisner & 27 & $\mathrm{~F}$ & cough, chest pain & benign & + \\
\hline 5 & 1988_Robinson & 27 & M & asymptomatic & benign & Unknown \\
\hline 6 & 1998_Smith & 53 & $\mathrm{~F}$ & cough & benign & Unknown \\
\hline 7 & 2003_Makida & 21 & M & asymptomatic & benign & + \\
\hline 8 & 2005_Angeles & 43 & $\mathrm{~F}$ & asymptomatic & benign & Unknown \\
\hline 9 & 2005_Bean & 51 & M & dysfagia & benign & Unknown \\
\hline 10 & 2006_Barrenechea & 38 & U & asymptomatic & unclassified & Unknown \\
\hline 11 & 2006_Yanagawa & 16 & $\mathrm{~F}$ & unknown & benign & + \\
\hline 12 & 2007_Segawa & 36 & $\mathrm{~F}$ & hoarsness & benign & + \\
\hline 13 & 2010_Ishibasi & 21 & $\mathrm{~F}$ & unknown & benign & Unknown \\
\hline 14 & 2011_Ponce & 28 & $\mathrm{~F}$ & asymptomatic & benign & Unknown \\
\hline 15 & 2012_Nakao & 66 & $\mathrm{E}$ & back pain & malign & + \\
\hline 16 & 2013_Luka & 64 & M & dyspnea, cough & malign & + \\
\hline 17 & 2014_Kim & 24 & M & asymptomatic & benign & + \\
\hline 18 & 2015_Kusano & 36 & M & cough & benign & + \\
\hline 19 & 2015_Shikatani & 19 & $\mathrm{~F}$ & pytosis, myosis & benign & + \\
\hline 20 & 2016_Winchester & 16 & M & asymptomatic & benign & + \\
\hline 21 & 2018_Ludovic & 41 & M & $\begin{array}{l}\text { dyspnea, pain, repeated } \\
\text { pericardial effusion }\end{array}$ & malign & Unknown \\
\hline 22 & 2019_Demiröz & 50 & $\mathrm{~F}$ & back pain & benign & + \\
\hline
\end{tabular}

GCT can occur almost anywhere in the body, but the most commonly affected site is the head and neck region, and particularly the oral cavity, followed by breast and skin regions $(3,6)$. Malignant $G C T$ s are reported to constitute only $1-3 \%$ of all GCTs $(2,4)$. In our review of literature, 17 of the 22 cases were benign, four were malign (18.2\%) and one was undefined. It can thus be concluded that the probability of malignancy is much higher in mediastinal GCTs then GCTs occurring in the other regions of the body.

The first malignant mediastinal GCT was reported by Harrer in 1972, after which, Fanburg-Smith et al. defined the histological criteria for malignant GCT. Mediastinal GCTs featuring at least three of the following criteria (necrosis, spindling, vesicular nuclei with large nucleoli, >2 mitosis per 10 high power fields, high nucle- ar/cytoplasmic ratio and polimorphism) are defined as malignant, although one must remember that the only real identifier of malignancy in GCT is metastasis (2-4). Clinically, all of the reported four malignant mediastinal GCTs were symptomatic, and three suffered from dyspnea, yet only one malign mediastinal GCT was reported to have distance metastasis (rib) and another malign patient developed liver metastasison in the postoperative sixth month $(4,7)$.

Diagnosing mediastinal GCT is a challenging task. Differential diagnoses include lymphoma, thymoma and neurogenic tumors, which are commonly seen in the mediastinum (6). There is no specific imaging study for the identification of mediastinal GCT. Thorax computed tomography, which is generally the first approach to defining mediastinal masses, generally shows a well-defined 
mass lesion in the mediastinum. Some authors have suggested that magnetic resonance imaging (MRI) is more helpful in distinguishing GCT from other neurogenic tumors of the mediastinum, although the enhancement pattern of GCT is different from the typical patterns of neurogenic tumors $(1,6)$. The role of $18 \mathrm{~F}-\mathrm{FDG}$ PET/CT in GCT is not clear. To the best of our knowledge, our case is one of the three mediastinal GCT cases evaluated by $\mathrm{PET} / \mathrm{CT}$, one of which was a malignant mediastinal GCT that had a higher FDG uptake (SUVmax: 12) than the other two benign cases (SUVmax: 4.11 and 4.13 respectively). According to the report by D'hulst et al. (8), metabolic activity on 18F-FDG PET/CT may help differentiate between benign and malign lesions, besides assessing the extent of the disease.

Minimally invasive biopsy techniques, including CTguided biopsy and endoscopic ultrasound-guided fine needle aspiration (EUS-FNA), were previously used to diagnose a mediastinal GCT (9); however it is difficult to confirm all cases of mediastinal tumor pathologically prior to surgery (10). As such, only three of the 22 cases (13.6\%) were diagnosed prior to a surgical intervention.

It is known that these tumors are not sensitive to chemo or radiation therapy, and the best known treatment is consequently total excision, made with clear margins to prevent local recurrence. As GCTs are usually well circumscribed, VATS is generally the approach of choice for the treatment mediastinal GCT (1).

\section{CONCLUSION}

Mediastinal GCT is an extremely rare neoplasia. To the best of our knowledge, this is the 22nd case reported in literature to date. Although there is an insufficient number of cases to support exact conclusions about mediastinal $G C T$, it can be concluded from the present report that mediastinal lesions are different in many ways from GCTs arising in other regions of the body in terms of their tendency be more malign in behavior, and also their occurrence in the younger population. That said, there is no difference in the histopathologic patterns of mediastinal GCTs and other GCTs. Preoperative diagnosis is challenging, and immunohistochemistry and ultrastructural techniques are required for a definite diagnosis. As it is known that these tumors are not sensitive to chemo or radiation therapy, the optimum treatment is total excision, made with clear margins. All GCT patients should be followed up for local recurrences, with malign GCTs followed up carefully even in the absence of distant metastasis at the time of diagnosis.
Table 2. The patient chracteristics of the all 22 mediastinal GCT cases (this case included) reported in literature.

\begin{tabular}{|c|c|c|}
\hline Age & $\begin{array}{l}\text { Range } \\
11-66\end{array}$ & $\begin{array}{l}\text { Mean } \\
34,7\end{array}$ \\
\hline Max dimension of mass $(\mathrm{mm})$ & $20-150$ & 53,47 \\
\hline & Number & Percent (\%) \\
\hline Gender & $\begin{array}{c}9 \\
12 \\
1\end{array}$ & $\begin{array}{c}41 \\
54,5 \\
4,5\end{array}$ \\
\hline $\begin{array}{r}\text { Symptom } \\
\begin{array}{r}\text { Asymptomatic } \\
\text { Cough or dyspnea } \\
\text { Pain } \\
\text { Horner's syndrome }\end{array} \\
\text { Repetitive pericardial effusion }\end{array}$ & $\begin{array}{l}9 \\
7 \\
4 \\
1 \\
1\end{array}$ & $\begin{array}{c}41 \\
31,8 \\
18,2 \\
4,5 \\
4,5\end{array}$ \\
\hline $\begin{array}{r}\text { Right } \\
\text { Left } \\
\text { Unknown }\end{array}$ & $\begin{array}{c}4 \\
7 \\
11\end{array}$ & $\begin{array}{c}18,2 \\
31,8 \\
50\end{array}$ \\
\hline $\begin{array}{r}\text { Surgery } \\
\text { Unresectable } \\
\text { Unknown }\end{array}$ & $\begin{array}{c}12 \\
1 \\
9\end{array}$ & $\begin{array}{c}54,5 \\
4,5 \\
41\end{array}$ \\
\hline $\begin{array}{r}\text { Benign } \\
\text { Malign } \\
\text { Unknown }\end{array}$ & $\begin{array}{c}17 \\
4 \\
1\end{array}$ & $\begin{array}{l}77,3 \\
18,2 \\
4,5\end{array}$ \\
\hline $\begin{array}{r}\text { Association with sympathetic nevre } \\
\text { Yes } \\
\text { Unknown }\end{array}$ & $\begin{array}{l}12 \\
10\end{array}$ & $\begin{array}{l}54,5 \\
45,5\end{array}$ \\
\hline $\begin{array}{l}\text { Immunhistochemistry } \\
\\
\mathrm{S} 100 \\
\mathrm{NSE} \\
\mathrm{CD} 68 \\
\mathrm{CD} 56\end{array}$ & $\begin{array}{l}+ \\
12 \\
5 \\
6 \\
3\end{array}$ & \begin{tabular}{c|c}
- & Unkown \\
10 \\
17 \\
15 \\
18
\end{tabular} \\
\hline Stain & 3 & 19 \\
\hline
\end{tabular}

\section{CONFLICTS OF INTEREST}

None declared.

\section{AUTHOR CONTRIBUTIONS}

Concept - S.M.D., G.F., G.Y., F.D., P.T.; Planning and Design - Ş.M.D., G.F., G.Y., F.D., P.T.; Supervision S.M.D., G.F., G.Y., F.D., P.T.; Funding -; Materials S.M.D., G.Y.; Data Collection and/or Processing S.M.D., G.F., G.Y., F.D., P.T.; Analysis and/or Interpretation - S.M.D., G.Y.; Literature Review - S.M.D., G.Y.; Writing - S.M.D., G.Y.; Critical Review - S.M.D., G.F., F.D. 


\section{YAZAR KATKILARI}

Fikir - S..M.D., G.F., G.Y., F.D., P.T.; Tasarım ve Dizayn S.M.D., G.F., G.Y., F.D., P.T.; Denetleme - Ş.M.D., G.F., G.Y., F.D., P.T.; Kaynaklar -; Malzemeler - S..M.D., G.Y.; Veri Toplama ve/veya İsleme - Ş.M.D., G.F., G.Y., F.D., P.T.; Analiz ve/veya Yorum - S..M.D., G.Y.; Literatür Taraması - Ş.M.D., G.Y.; Yazıyı Yazan - Ş.M.D., G.Y.; Eleştirel İnceleme - Ş.M.D., G.F., F.D.

\section{REFERENCES}

1. Machida E, Haniuda M, Eguchi T, Kurai M, Yamanda T, Amano J, et al. Granular cell tumor of the mediastinum. Intern Med 2003; 42:178-81. [CrossRef]

2. Angeles RM, Papari M, Malecki Z. Pathologic quiz case: a 43-year-old woman with an incidentally detected posterior mediastinal mass. Granular cell tumor of the posterior mediastinum. Arch Pathol Lab Med 2005; 129:e278.

3. Kusano J, Iguchi F, Takahashi Y, Terada Y, Murai N. Neck and superior mediastinal granular cell tumor excised via a combined approach. Auris Nasus Larynx 2015; 42:72-6. [CrossRef]

4. Nakao M, Hishida T, Ishii G, Yoshida J, Nishimura M, Nagai K. Malignant granular cell tumor of the posterior mediastinum with dissemination. Asian Cardiovasc Thorac Ann 2012; 20:71-3. [CrossRef]

5. De Luca G, Luciano A, Benincasa G, Sessa R, Petteruti F. Giant malignant granular cell tumor (GCT) of the posterior mediastinum. J Thorac Oncol 2013; 8:1107-8. [CrossRef]

6. Kim DY, Jeon HW, Kim KS, Park JK, Sung SW. A rare case of mediastinal granular cell tumor. Korean J Thorac Cardiovasc Surg 2014; 47:494-6. [CrossRef]

7. Harrer WV, Patchefsky AS. Malignant granular-cell myoblastoma of the posterior mediastinum. Chest 1972; 61:95-6. [CrossRef]

8. D'hulst L, Deroose C, Strybol D, Coolen J, Gheysens O. 18F-FDG PET/CT and MRI of a mediastinal malignant granular cell tumor with associated recurrent pericarditis. Clin Nucl Med 2018; 43:589-90. [CrossRef]

9. Bean SM, Eloubeidi MA, Eltoum IA, Cerfolio RJ, Jhala DN. Preoperative diagnosis of a mediastinal granular cell tumor by EUS-FNA: a case report and review of the literature. Cytojournal 2005; 2:8. [CrossRef]

10. Shikatani Y, Okazaki M, Sakao N, Yukumi S, Shigematsu $\mathrm{H}$, Kitazawa $\mathrm{S}$, et al. A case of mediastinal granular cell tumor with Horner's syndrome. Ann Thorac Cardiovasc Surg 2015; 21:567-9. [CrossRef] 